\title{
A REVIEW OF GOVERNMENT INTERVENTIONS PROMOTING SMALLHOLDER DEVELOPMENT IN INDONESIA
}

\author{
Zahari Zen \\ Magister Management \\ Faculty of Economics and Business UHM \\ Medan, Indonesia \\ zahari.zen@gmail.com
}

\author{
Tapi Rondang Nibulan \\ Magister Management \\ Faculty of Economics and Business UHM \\ Medan, Indonesia \\ tapinibulan@yahoo.com
}

\begin{abstract}
Oil palm against a background of widespread poverty in the outer islands, where a large, very poor rural population that was not technically conversant with high input agriculture lived side by side with a prosperous commercial estate plantation sector. While many smallholders in these regions cultivated trees including oil palm as a spread effect from estates, their stands have tended to be low-yielding and land-extensive, providing low returns per unit of area compared to large plantation. Development of smallholders needs to occur alongside large oil palm expansion programs which is driven by large plantation companies. As this review, the productivity of independent smallholders is less than $50 \%$ of large plantations. Smallholder yields can be improved via PIR type schemes through a $60: 40$ scheme $(60 \%$ for plasma and $40 \%$ for the nucleus estate). Though current partnership scheme (20:80) is less effective and difficult to accept, it has created many land disputes. Under 60:40 schemes, estate will accommodate both smallholder expectations for oil palm cultivation as well as estate economies of scale. This will provide companies with a social license to operate and ensure company viability over the longer term. Policies and schemes can help secure the rights, resources and livelihoods of the rural poor
\end{abstract}

Keywords - Independent smallholders, PIR type schemes, conflict, Government interventions, poverty, plantation laborers

\section{INTRODUCTION (HEADING 1)}

This template, modified in MS Word 2007 and saved as a "Word 97-2003 Document" for the PC, provides authors with most of the formatting specifications needed for preparing electronic versions of their papers. All standard paper components have been specified for three reasons: (1) ease of use when formatting individual papers, (2) automatic compliance to electronic requirements that facilitate the concurrent or later production of electronic products, and (3) conformity of style throughout a conference proceedings.
Margins, column widths, line spacing, and type styles are builtin; examples of the type styles are provided throughout this document and are identified in italic type, within parentheses, following the example. Some components, such as multileveled equations, graphics, and tables are not prescribed, although the various table text styles are provided. The formatter will need to create these components, incorporating the applicable criteria that follow.

\section{GOVERNMENT AND MEASURES OF IMPROVEMENT}

Indonesia adopted initiatives utilizing oil palm and other tree crops against a background of widespread poverty in the outer islands, where a large, very poor rural population that was not technically conversant with high input agriculture lived side by side with a prosperous commercial estate plantation sector. While many small farmers in these regions cultivated trees including oil palm as a spread effect from estates, their stands have tended to be low-yielding and landextensive, providing low returns per unit of area compared to industrialized planation agriculture. At the same time, the widespread provision of timber plantation and oil palm estate licenses put great pressure on land areas classified as forest estate, in an environment already diminished through timber extraction. Indeed, the World Bank has reported that $70 \%$ of Indonesia's oil palm plantations were on land which previously formed part of the national forest estate. A current major concern for ecologists (and, increasingly, economists predicting the financial risks of climate change) is that many plantations have been established on peat lands, destroying vulnerable ecosystems and generating vast carbon emissions.

Although a few smallholders made autonomous transitions to high-yielding varieties and secured major income increases, these tend to be staff and workers from estates along with some financially well-endowed local business people. While relatively few ordinary farmers took such action, as these progressive farmers became successful, they bought up large 
areas of land, creating the issue of agrarian differentiation and rising inequality (McCarthy 2012). In this context, government or a civil society organization might intervene to secure the shift to a more productive oil palm agriculture.

State planners have seen some regions of the outer islands as suffering especially from severe poverty and environmental problems. Accordingly, planners have paid particular attention to secure regional development in these areas, including Southern Sumatra, and Eastern, Western and Central Kalimantan. State decision makers saw the Kalimantan locations, in particular, as being covered by large areas of the creeping and economically useless grass, alang-alang/ Imperata cylindrica, which they viewed as the legacy of deforestation by timber companies and illegal loggers, or of clearing for food crop cultivation in transmigration schemes (Dove, M. (1986). Human Ecology 14(2) 1986 pp 163-190). The policy view was that the frequent burning during the dry season of both alang-alang and peat land and unutilized timber posed additional environmental hazards through smoke and haze, as this damaged the health of residents in these areas. These circumstances were seen as justifying the issue of long term lease HGU titles (Hak Guna Usaha) to companies without substantial payments, in the process securing what state decision makers saw as a better option: oil palm development.

From a policy maker's perspective, a development strategy should aim to introduce socio-economic improvements that match local resources with climatic endowments, providing agricultural production models that can be adopted sustainably and profitably by local farmers and transmigrants. If yieldincreasing forms of agriculture are also introduced, which are more intensive, this will reduce the pressure on the limited area of land available. From a national planning viewpoint, planners could justify the approaches that generate higher national income and foreign exchange. In the early years, official smallholder plantation policy focused on rubber, which was already well known to local people, cultivated in low-yielding mode over vast areas, and marketed through a competitive chain of traders. In those years, decision makers were building on an existing base; an easier alternative to starting with food crops. But from the mid-1980s, the revenueearning superiority of oil palm over rubber became clear, and the chief thrust of new initiatives became focused on this newer crop.

For the state development planners, the principal constraints facing improvement plans remained the scarcity of development capital, although this was not acute until the 1997 financial crisis. Where the tree crop extension services or Dinas Perkebunan lacked adequate staff and were perennially underfunded, the more immediate challenge continued to be the shortage of skilled personnel to implement the changes thought appropriate. The rubber improvement schemes of the 1970 s and early 1980s, which were largely implemented by the Smallholders' Rubber Development Program, progressively overcame this problem by building a most effective operation with funding from the World Bank (Zen,
1998). This separate venture, taking place alongside the traditional tree crop extension services, engineered most new initiatives over those years.

However, when state planners and investors became interested in oil palm, the focus changed. Given the vast size of schemes envisaged, and the need to have large palm oil mills to ensure the necessary economies of scale, in addition to state support, state planners turned to private estates. Private sector actors had the required managerial and technical skills, huge palm oil mills, and ready access to capital. The Commonwealth Development Corporation had pioneered the 'nucleus estate' model in Africa in the 1950s. By now, states had widely employed this approach on that continent (Graham and Floering 1984). The Indonesian authorities adopted this model, and from the late 1970s to 2000 applied it to large areas.

\section{A. Nucleus Estates (Heading 2)}

For the purpose of smallholder development, the nucleus estates policy aimed to provide a 'package' comprising management, technology including high-yielding trees, and services entailing the opening and planting of land, the supply of inputs, and processing fresh fruit bunch. The government made this package available with a commercial nucleus or 'core' (inti) managed by large estates, and a surrounding plasma of smallholdings in 2-3 ha units. From the late 1970s, the policy put pressure on estates to undertake such plasma development, in return giving them 'free' access to land for inti and providing subsidized capital for inti and plasma development.

A total of almost 900,000 ha of smallholders plasma took up nucleus estates smallholdings until 2013 (Table 1), involving 450,000 settlers and almost 2 million people. For many years the policy allocated $20 \%$ of the total nucleus estate area to the inti, but this rose after 1998 to $30 \%$, reducing the estate risk and enhancing economies of scale. The usual arrangement was for estates to clear the plasma land, plant the tree crop, and administer the development for four years, during which time some employment was offered to the settlersmallholders.

After this an elected settler cooperative took responsibility for administration of the plasma, normally contracting the estate to continue the functions of management, extension and provision of services. The cooperative handled the repayment of plasma development loans, with $30 \%$ of the net crop proceeds being deducted to cover the subsidized interest of $12 \%$ and charges for inputs and services. The estates benefited through their fees for services, and through their returns from milling smallholder fruits into crude palm oil. 
Table 1. Composition of smallholder under PIR and independent smallholders

\begin{tabular}{|c|l|c|c|}
\hline \multirow{2}{*}{ Table Head } & \multicolumn{3}{|c|}{ Smallholdings } \\
\cline { 2 - 3 } & \multicolumn{1}{|c|}{ Type of schemes } & $\begin{array}{c}\text { Acreage } \\
(\text { Ha })\end{array}$ & $\begin{array}{c}\text { Total } \\
\text { Acreage } \\
(\text { Ha })\end{array}$ \\
\hline \multirow{2}{*}{ Plasma } & NES, PIR-SUS, PIR-Lokal & 153.388 & \multirow{2}{*}{899,100} \\
\cline { 2 - 3 } & PIR-TRANS & 362.528 & \\
\cline { 2 - 3 } & KKPA & 155.211 & \\
\cline { 2 - 3 } & REVITBUN & 227.981 & \\
\hline $\begin{array}{l}\text { Non-Inti } \\
\text { Smallholders } \\
\text { Scheme }\end{array}$ & $\begin{array}{l}\text { Independent } \\
\text { Smallholders }\end{array}$ & 2.874 .418 & \multirow{2}{*}{$2,874,418$} \\
\hline \multicolumn{3}{|c|}{ Total acreage } & \multirow{2}{*}{ Source: Direktorat Jenderal Perkebunan, 2013 } \\
\hline
\end{tabular}

Five types of nucleus estate were established from the beginning in 1978, While the first, known as PIR Lokal, only provided for surrounding farmers, subsequent types catered for both transmigrants and locals, with the former who often came from failed local cash crop schemes often given priority. One problem persisted from the start, and policy makers never properly rectified it: over the four years before the oil palm became productive, schemes provided inadequate income for subsistence. Although the estates sometimes employed settlers, notably in opening and planting the plasma land, this was not generally satisfactory. Schemes did not allow settlers to intercrop their young oil palm stands, where this could have substantially supplemented their returns. Further, over the first two decades, the nucleus oil palm mills did not pay satisfactory prices for their crops of 'Fresh Fruit Bunches' (FFB). Policy makers only improved this from 1997 when they altered the official 'formula' for this purpose. Even then, the 2.0 hectares of oil palm per settler hardly provided a reasonable income, especially in the early lower-yielding years. After 1997 the schemes allowed participants to plant oil palm on their additional 'cash crop' area of 1.0 hectare, and the participants universally took advantage of this.

If settlers could sustain themselves through this period, their situations usually improved greatly when their palms came into full production after 9-10 years. Provided the cooperative operated well, the palm oil was produced according to its potential and the governance arrangements functioned effectively, this stage provided smallholders with the opportunity to complete both their principal and interest repayments. Although there were exceptions, most of the farmers in plasma areas established up to the mid-1990s were doing well by the mid-2000s. There was considerable variation in performance between different nucleus estate schemes.

The competence of the nucleus estates management shaped outcomes, affecting the way the land was originally converted', the quality of the planting material and how it was cultivated, the standard of the product, the handling of settlers, and relations with cooperatives and other parties, including local governments and transmigration officials. For estate managements geared to profitably running commercial units, the realm of socio-economic improvement for smallholders involved new challenges, with a temptation and indeed a tendency to emphasize the production needs of inti over the smallholder area, given that this was after all the 'profit core' of their operation.

From the late 1990s, major political changes complicated the situation, impinging upon the relations of estates with the local communities. Estate managers frequently took a heavyhanded approach, making it hard for them to solve the serious land problems. These land problems arose from a variety of practices during the New Order. Critics have argued that oil palm development continued a process of state-supported extinguishment of customary or 'informal' land rights that had commenced in the 1970s (Barlow, 2001). A governance minefield opened up as, in allocating land to estates, state policy involved the forcible enclosure of areas that were previously cultivated by local villagers or subject to various customary or community claims. Under New Order practices, the original owners only received nominal compensation. In many cases, such transfers were not properly documented, and took place in an intimidating situation. As oil palm estates thrived, villagers who were left watching this affluence generated from their former lands became bitter (Soeleiman, 2000).

Given the growing community bitterness, estate lands were frequently disputed, and many hundreds of individual parcels within plasma areas of several thousand hectares became subject to land claims. To settle disputes under the changed political conditions, estates wishing to develop new areas needed to secure individual agreements. Where relations with landholders were not well managed, this generated prolonged disputes. In many cases, local settlers contended that they were entitled to more smallholdings above their entitlements under the schemes, because they had contributed extensive areas of land to the schemes. In many cases, local farmers contributed their land to the nucleus estates without being later included in the plasma. Field studies found that that these difficulties often led to the freezing of large blocks, including those in existing plasma, disrupting operations for long and at times indefinite periods.

Estate managers often had disagreements with local governments. Following decentralization, these disputes became more serious, as the district administration gained discretionary powers. It took some time for a generation of managers used to ignoring local officials to realize they now needed to develop rapport with local officials, who could otherwise make operations very difficult for them. In one case studied in the province of Bengkulu (Zen, et. al. 2003), the district head (Bupati) blockaded the main access road into the estate for several months, making it hard to export its produce until the estate agreed to defer on a particular issue.

In several cases, interviews revealed that managers lacked competence even in running normal commercial operations, and this carried over into the plasma where, for example, wage payments to workers were delayed and lower than the amount agreed to earlier. In a case in West Sumatera, furious settlers took over the estate offices and ran the operation themselves. In another case in West Sumatera only 200 hectares of a 500 
hectare plasma had been poorly developed after several years, since the technically competent estate management was unable to establish workable relations with the local settler groups (Zen and Wahyono 2006).

Discussions with farmers and estate staff revealed that the transfer to settlers of the requisite skills also proved difficult, especially when settlers in the schemes had non-agricultural backgrounds. In some cases it took many years for such settlers to competently handle their areas, especially given that harvesting and other operations required much expertise. When managers used to dealing with hired workers ignored this training problem, the results were inevitably poor. However, where estates instituted proper and sympathetic extension, the schemes could increase net returns for all concerned. Indeed, many estate companies adjusted well following earlier setbacks, managing to achieve excellent results.

During a field visit to several estates in 2003-2005, it became clear that one large corporation engaging in numerous nucleus estates had set up a special section to deal with settler extension and community relations, concentrating on the 20$30 \%$ of participants with particular difficulties (Zen, et. al. 2006). This company, whose commercial results were already excellent, secured better than average settler performances and cordial relations, raising both its own and the settlers' earnings. This was still within the framework of discipline and effective supervision necessary in such extensive operations. Commercial companies tended to perform better than government estates in the nucleus estates program, due to more imaginative and flexible styles of management, and as their pursuit of the 'bottom line' provided incentives to manage settlers more effectively.

Apart from the problems in plantation management, however, difficulties also arose when the Department of Transmigration and Manpower selected unsuitable settlers who failed completely, and eventually dropped out of the schemes.

A 1989 World Bank Group (WBG) review of its oil palm portfolio found that the management capacity of Indonesian state-owned enterprises was low. The government had been slow to pass funding on to enterprises, and overall, several loans had performed poorly. The WBG concluded that the Indonesian palm oil sector needed to be driven by the private sector (CAO 2009).

Indonesian policy then began to shift from the state-led to a private sector orientation. In 1995 the government introduced the 'Primary Cooperative Credit Scheme' (KKPA). Now, rather than poor transmigrant settlers brought in from Java and Bali under many of the earlier schemes, indigenous villagers were offered incentives to give up large areas of land to the plantation estates. In return they would obtain a two hectare oil palm smallholding (McCarthy 2009). In other words, indigenous landowners would provide land to the estate in return for obtaining a productive smallholding and access to agricultural inputs and guidance. Under this scheme, low interest loans were provided by Bank Indonesia. These KKPA schemes developed approximately 192,725 ha of plasma smallholders and 78,524 ha of nucleus estate (Dirjen Perkebunan, 2008). The government policy aimed to speed up smallholder oil palm development, and rehabilitate earlier smallholder plasma areas. The KKPA schemes represented a withdrawal from earlier market interventions, as the state was now much less involved in the early phase of estate development.

Again, Bank Indonesia, which provided funding under the KKPA program, was frequently slow in its disbursements to the commercial banks which managed the loans, while the latter banks coordinated poorly with both the Department of Agriculture and estate companies. This led to delays of months or even years in land clearing and planting, incurring higher expenditures in the interim to support plasma farmers. Interviews with project stuff and farmers revealed that cooperatives on occasion functioned poorly, especially in earlier years when those responsible had to engage in a massive learning process, and corruption amongst the elected officials led to losses of settlers' money. However, these complications were again often surmounted. In many instances co-operatives improving their administration after an increasingly knowledgeable and vociferous cooperative (plasma) members applied pressure and demanded changes.

Despite these problems of nucleus estates, however, estimates based on these study, and using currently forecast prices, indicate quite reasonable average outcomes (Table 2 and Table 3). The estimated mean internal rate of return (IRR) of plasma over the 28 years involved is $15 \%$, after deduction of land charges which in practice do not always apply. This compares with an estimate of $18 \%$ after land charges for purely commercial estates. A good part of the substantial net return per $\mathrm{kg}$ of the plasma (Table 2) flows back to the settlers, adding to the 'wage' of Rp21.000 or US\$2.3 per day paid for harvesting and other manual inputs.

Table 2. Expected Prices, Yields and Costs

\begin{tabular}{|c|c|c|c|c|}
\hline \multirow[b]{2}{*}{ Items } & \multicolumn{4}{|c|}{ Type of schemes } \\
\hline & Estates & $\begin{array}{l}\text { Plasma } \\
\text { s/holding }\end{array}$ & $\begin{array}{c}\text { High- } \\
\text { yielding } \\
\text { s/holding }\end{array}$ & $\begin{array}{c}\text { Low- } \\
\text { yielding } \\
\text { s/holding }\end{array}$ \\
\hline $\begin{array}{c}\text { Factory-gate Price } \\
\left(\mathrm{Rp} / \mathrm{kg} \mathrm{FFB}^{\mathrm{a}}\right)\end{array}$ & 600 & 573 & 495 & 441 \\
\hline Yield of FFB ( $t / h a)$ & 21.3 & 19.0 & 17.0 & 10.0 \\
\hline Interest Rate (\%) & 12 & 12 & 12 & 12 \\
\hline Wage (Rp/day) & 21,000 & 21,000 & 18,900 & 18,900 \\
\hline 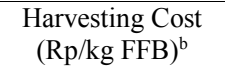 & 60 & 60 & 54 & 54 \\
\hline $\begin{array}{c}\text { Overheads (Rp/kg } \\
\text { FFB }\end{array}$ & 19.8 & 18.9 & $5.4)^{\mathrm{c}}$ & $2.7^{\mathrm{c}}$ \\
\hline $\begin{array}{l}\text { Capital (Rp/kg } \\
\text { FFB }^{\mathrm{d}}\end{array}$ & 9.0 & 10.1 & 8.8 & 1.7 \\
\hline Land $(\mathrm{Rp} / \mathrm{kg} \mathrm{FFB})^{\mathrm{e}}$ & 28.2 & 31.6 & 35.3 & 50.0 \\
\hline 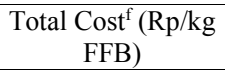 & 289.4 & 299.8 & 265.3 & 290.6 \\
\hline $\begin{array}{l}\text { Net Return }{ }^{\mathrm{g}}(\mathrm{Rp} / \mathrm{kg} \\
\text { FFB) }\end{array}$ & 310.6 & 273.2 & 229.7 & 150.4 \\
\hline $\begin{array}{l}\text { Official Investment } \\
\text { Cost ('000 Rp/ha) }\end{array}$ & - & 19,019 & 1,300 & - \\
\hline
\end{tabular}


Notes:

a) Fresh Fruit Bunches

b) All-in, including value of housing and all perquisites provided to workers.

c) Assuming that the overheads of high and low-yielding smallholdings are 30 and $50 \%$ respectively of those on estates and plasma holdings.

d) Charge for interest on working capital in the enterprise.

e) Charge for interest on the value of land.

f) Including Upkeep, Fertilizer, Harvesting, Overheads, Capital, and Land (but not expenditures on any services provided by government departments including the Dinas Perkebunan and Biro Transmigrasi).

g) Factory-gate price less Total Cost as defined in 'official investment'

In the case of the plasma smallholding, this is the total cost including overheads of getting the stand up to year 4 when it commences production. Most of this cost is repaid at interest by the smallholders concerned, but that could take 6-8 further years. In the case of the high-yielding smallholding this is the cost of providing the subsidized seedlings and the accompanying extension by the Dinas Perkebunan.

Yet these results subsume considerable differences between settlers. In the course of this study the researchers checked individual farmer's record books, finding a variation of at least $50 \%$ around mean plasma yields. Again, some nucleus estate plasma, particularly those making the adjustments just discussed, did much better than average. But even most of the worst performing entities have survived, although the returns per settler were much lower.

In an overall assessment, the nucleus estates may be judged a moderate success, despite the problems demanding solutions if the route is to be further developed.

\section{B. Innovations post 1999}

After the East Asian Crisis, Indonesia witnessed a debate on how socio-economic improvement might be achieved through oil palm development. While earlier initiatives certainly had positive impacts, rural poverty remained widespread in the outer islands of Indonesia. Advocates of further expansion argued that growing oil palm in targeted schemes could overcome this. Policy makers still considered the development of nucleus estates as the chief framework for the future. Clearly, following decentralization, district and provincial governments would have a more substantial role.

Given the reduced financial capacity of the state and the shift towards more market based philosophies, state policy shifted further towards private sector models of oil palm development. These innovations and their performance are now examined in more detail, before we consider how they might be developed in coming years

\section{IMPROVEMENT OF INDIVIDUAL SMALLHOLDINGS}

A majority of the current area of Indonesian individual oil palm smallholdings is planted with low-yielding palms, whose estimated average annual yield of FFB is only 10.0 tons per ha compared to the 21.3 tons in estates (Table 3 ). Smallholders generally purchase from small private nurseries or travelling traders. The low prices per seedling of Rp4.000 or US\$0.44 appeal to farmers short of cash and needing to establish around 140 palms per hectare. Given that farmers lack technical knowledge regarding high quality planting material, it is difficult for them to distinguish between such poor materials and the more than twice as expensive high-yielding seedlings sold by large nurseries, or seedlings which can sometimes be accessed directly from estates. Nurseries offering high quality material tend to be difficult to access and hence purchasing seeds from them would involve additional costs. In many cases, inferior palms are planted haphazardly without terracing, and fertilizer applications tend to be low. Given that these are local smallholders, they can usually access land without the substantial charges that tend to be applied to estates and other outsiders. They accordingly secure an estimated IRR (without land costs) of 19\% (Table 3), but their lesser outputs mean they obtain only half the estimated net present value of the plasma holdings. Compared to the modern planation sector, this is a significant disparity.

Consequently, oil palm developments are associated with highly differentiated outcomes for smallholders. While some programs have brought marginal farmers out of poverty, oil palm developments don't necessarily lead to such outcomes. A stratified survey among farmers, laborers and landholders across two villagers showed that farmers could prosper provided that they retain control over the two hectares of oil palm land they had been allocated under a KKPA scheme, and provided that they manage the labor process themselves, and receive monthly payments from the plantation company based on the volume of product they provide. The survey found that farmers with 2 hectares of oil palm had net savings (the income left after all costs were met) that were on average four times higher than villagers without high quality oil palm smallholdings. Those with more than 4 hectares of oil palm were on average 8 times better off than the farmers with two hectares (McCarthy 2013). The rapid expansion of over 15\% per year for the last 15 years attests to the economic attraction that oil palm holds for local farmers/independent smallholders.

Yet, smallholders face many challenges. They need access to substantial funds to purchase superior planting material, fertilizers and pesticides, and they need to develop strong planting and harvesting skills. Many have trouble getting fresh fruit bunches to mills in time, especially in the wet season or in remote areas where roads were poor. The result has been that smallholders might achieve only $24 \%$ of the productivity of the average plantation, and just $12 \%$ of the productivity of bestpractice plantations (CAO 2009).

Most local smallholders have little contact with plantation extension officers. In contrast, where the local plantation office (Dinas Perkebunan) had contact with individual smallholdings during earlier periods, this led to the distribution of highyielding materials from reputable nurseries. In the case of rubber a small proportion of smallholders, who could plant better trees and employed improved husbandry, achieved twice the yield over the 20-year life of the stands (Barlow and Muharminto 1982; Zen 1997). In some cases similar results have been achieved with oil palm. For instance, similar outcomes were achieved between 2000 and 2010 where the 
Indonesian Oil Palm Research Institute (IOPRI), the local Dinas Perkebunan, and local estate companies developed a joint initiative in several locations. The companies set up large nurseries selling improved seedlings at subsidized prices, with the Dinas Perkebunan carrying out an extension program that led to widespread tree adoption.

In the three years to 2014, IPORI has implemented a special mobile program of selling subsidized seeds and providing extension services for smallholdings in Sumatera, from villages of Aceh to Lampung. The aim is to convince the community that illegal seed is dangerous for their OP cultivation. However, the budget to support these activities is currently too small. If the government begins to support these activities fully, the mobile program can scale up and have a significant impact on community welfare. The IOPRI model to support independent smallholders could also be scaled up using companies' CSR budgets.

But these initiatives have, like the nucleus estates, been affected by the recent political changes, notably by the decentralization in which the local Dinas are now almost exclusively under the control and financial jurisdiction of districts showing varying degrees of interest in rural improvement. Sometimes, and especially in the richer provinces including Riau, Aceh and East Kalimantan, the programs of the Dinas have been strongly bolstered, and assisted further by special subsidized loans. In other instances, however, the Dinas are even more constrained than they were under the New Order, where they were at least assured of a minimal level of finance.

The impact of market liberalization and the development of independent farmers' production, followed by the emergence of CPO mills that are not associated with their own oil palm areas, has meant that previously independent smallholders now do not depend on government-owned private estates to sell their fresh palm fruit bundles. The large corporations have protested against the CPO mill loss of fresh fruit bundles from their area, which has accounted for $10-15 \%$ loss per year (Zen, et. al. 2006).

The Plantation Act (No. 18 / 2004) holds that palm oil mills that lack their own plantation areas should be closed by the end of 2007. However, the government has yet to close a single palm oil mill without a plantation (Zen et. al. 2015).

More wealthy local investors have also planted highyielding oil palm, sometimes planting quite large areas of up to 10-20 ha. At the same time, more 'traditional' smallholders, frequently in-migrants (pendatang) from other parts of Indonesia, have moved into frontier areas to plant high quality materials on their 2-3 hectares. These smallholders have received input from both the Dinas Perkebunan and their bigger, more knowledgeable smallholder neighbors. Their estimated average yields were reasonable, at an estimated 17.0 tonnes per hectare (Table 2). With labor and other costs being lower than those of estates, they managed a mean IRR of $18 \%$ after land charges, with a quite substantial net present value (Table 3).
Table 3. Expected Internal Rates of Return (IRRs) and Net Present Values (NPVs)

\begin{tabular}{|l|c|c|c|c|}
\hline \multirow{2}{*}{$\begin{array}{l}\text { Investment } \\
\text { parameters }\end{array}$} & Estates & $\begin{array}{c}\text { Plasma } \\
\text { s/holding }\end{array}$ & $\begin{array}{c}\text { High- } \\
\text { yielding } \\
\text { s/holding }\end{array}$ & $\begin{array}{c}\text { Low- } \\
\text { yielding } \\
\text { s/holding }\end{array}$ \\
\cline { 2 - 5 } & 18 & 15 & 18 & 12 \\
\hline $\begin{array}{l}\text { IRR (\%) } \\
\text { - With land cost } \\
\text { Without land } \\
\text { cost }\end{array}$ & 20 & 16 & 21 & 19 \\
\hline $\begin{array}{l}\text { NPV (Rp'000) } \\
\text { - With land cost } \\
\text { - Without land }\end{array}$ & 11,852 & 6,066 & 6,975 & Negative \\
cost & 15,477 & 9,720 & 10,832 & 4,485 \\
\hline
\end{tabular}

Source: Data secured in the Group's Indonesian Oil Palm Study,2005

To sum up, many landowners in oil palm districts remain relatively poor because they failed to be integrated into schemes, or be provided access to the capital and the knowledge required for inclusion into the palm oil industry on positive terms. Inequality increases as large scale plantations spread, and conflicts emerging from unresolved grievances continue as long as many landowners integrated into the palm oil industry on adverse terms.

In contrast, those who established high-yielding trees on independent smallholdings secured useful increases in income. If this approach were to be extended to more 'traditional' smallholders, it would mark a significant advancement. It is hard to estimate the current extent of such improved holdings, but it probably does not exceed 250,000 hectares in the total of over 900,000 hectares of individual oil palm holdings (Table 1). Therefore, a great deal of further improvement could be achieved. In many ways, advances through small independent smallholdings are more flexible than those through the comprehensive packages of the estate schemes that require careful control. In addition, they involve much less government financing to support their establishment, and this is most advantageous when development capital is scarce. Independent smallholders are also more appropriate to the new Indonesian era of devolution and greater individual independence. Suggestions on how this approach might be made more effective are included in the conclusions.

In addition, both nucleus estate and individual smallholding operations generate spread effects. These effects emerge from the training, and encouragement to plant elsewhere, of persons involved. Visits to field locations demonstrate that numerous plasma settlers had planted high-yielding trees on land outside the nucleus estates, while some individual smallholders who had planted high-yielding material had subsequently decided to extend their operations. More progressive surrounding farmers observe the improvements made by their colleagues, consult these colleagues, and use their advice to plant high-yielding stands themselves. There are always considerable lags in such dissemination of innovation, however; first in the learning process, and second in the time needed to amass sufficient capital to take action. But these spread effects should certainly be taken into account in assessing the final results of oil palm policies that aim to achieve socio-economic improvements. At the same time, these spread effects involve successful farmers buying up large areas of land, sometimes in crisis sales from impoverished local landowners. This occurs during processes 
of agrarian differentiation, and is associated with the emerging problems of landlessness (McCarthy 2010).

\section{REVITALISASI PERKEBUNAN RAKYAT SCHEMES}

After 2006, state policy makers introduced the plantation revitalization scheme, which initially targeted 1.5 million ha. Under this scheme, the state and private estate could obtain subsidies for replanting older plasma smallholder areas. Farmers would receive a state-subsided loan, but under the scheme's benefit sharing arrangements, farmers can retain only $20 \%$ of the income generated from their revitalized smallholding. Smallholders have been reluctant to take on this debt for such limited benefits (Kompas 2009). Interviews during 2008-9 also revealed that banks were requiring that 'core' estates provide security for loans for developing smallholder areas before offering lines of credit. 'Core' estates were reluctant to take on such liabilities for loans that they argued were insufficient to subsidize the costs entailed in developing plasma areas. Consequently, the realization of revitalization schemes has been held back.

Another problem is the credit limit for the revitalization program is very low. The program could not be readily rolled out given the variation in field conditions across the country. The revitalization program mostly worked on replanting plasma PIR/NES schemes which had crops that were now too old and where the land conditions were relatively clean. Independent smallholders could not readily access funding for the replanting package, in part due to the low ceiling cost, which were inadequate for land clearing activity. Consequently program implementation was slow, and it had hardly improved the condition of independent smallholders.

\section{A. Local Government Initiatives in West Kalimantan and Riau}

When the nucleus estate program commenced, Indonesia was still in the highly centralized and authoritative mode of the New Order government. But, since 1999, this has been superseded, first by the newly important influence of local legislatures, and then after 2001 by the decentralization arrangements of otonomi daerah. The increase in influence of local politicians, and the placing of most of the administrative and financial power in the hands of districts, influenced socioeconomic initiatives; not only through the nucleus estates but also through the extension by the district plantation agencies (Dinas Perkebunan). These changes have certainly had benefits, but also posed new constraints. The financial crisis of 1997 additionally occasioned a slowing of the nucleus estates, and, in fact, there has been no further government-sponsored expansion of these units since 2001. But several private estate companies continued to establish estates with their own resources, partly as a means of getting hold of more land for their commercial operations. Under new government regulations, the private companies were still obliged to include smallholders in their operations .Under Nucleus Estate Schemes $70 \%$ of land needed to be provided for smallholders.

Under the new 'partnership' or kemitraan model, plantations could negotiate land and benefit sharing arrangements directly with participating farmers, without the direct involvement of state agencies. Under this model, plantation companies could take control of up to $80 \%$ of the development areas and smallholders needed to obtain at least a $20 \%$ share. This smallholder share could take the form of a 'dividend' from the estate - amounting to the equivalent of the production benefit that they might derive from production from the same amount of land. Alternatively, the estate development might directly return $20 \%$ of the estate development to smallholders for cultivation . Companies now could gain direct control of up to $80 \%$ of the development area, rather than $30-40 \%$. This provided a strong incentive for large capital-intensive companies to invest in oil palm. These occurred as local government pursued policies at crosspurposes with central government policy, with low development budgets and with ongoing land conflicts as land becomes increasingly scarce (McCarthy and Zen, 2009).

With Districts gaining significant discretionary powers under decentralization (otonomi daerah), the partnership (kemitraan) policy between large companies and smallholders has left space for a wide variety of initiatives. Consequently the shape, significance and application of kemitraan policies very much depend on the conditions and policies of particular Districts. Here below we discuss two Kabupatens as examples of different local government arrangements, and consider their impacts on rural landowners.

\section{1) The case of Kemitraan in Sanggau Kalimantan}

In 2008, research in the district of Sanggau in West Kalimantan found that district policy makers has sought to attract investors through pro-plantation policies, granting 12 new plantation licenses for an additional 240,000 ha of planned oil palm development. The Kemitraan policy framework allows for various benefit sharing options and landholder arrangements. Under this framework, District legislation obligates plantation developers to allow for, at least, an 80:20 land system split. Under these provisions, for example, local landowners might relinquish 16,000 ha of village land for 4000 ha of individually certified oil palm smallholding. Farmers who choose to participate only receive a traditional payment for loss of perennial crops, and do not receive payment for the land itself. They also have to pay credit for infrastructure development, investment and operational costs when the trees become mature.

One Sanggau plantation had already come into production under the Kemitraan arrangement. Here, the estate determines the price of FFB produced from plasma land, as provided for by national law, setting up a regional commission to ensure smallholders obtain a price that reflects the international market. Each farmer, who has plasma of 1.56 ha with trees of 9 years of age, obtained just Rp296, 913 or US\$ 25.5 per month. Participating farmers fall below the poverty line of Rp750, 000 or US\$64.3 per month, as set by Asia Development Bank. To put this in perspective, we compared this to the amount a landowner would receive under the substantially more favorable PIR Trans 70:30 arrangement. 
From the same area of land, farmers would receive Rp1,039,196 or US\$89 per month from 1.56 ha and under the same FFB price. This indicates that Sanggau Kemitraan schemes represent a step backwards for smallholders in term of economic wellbeing and land ownership.

Another study of a plantation that developed under this dividend-based partnership model also confirmed that the model performed poorly for smallholders. Plantations had taken over village land without compensation, and although smallholders were required to hand over their land for the plantation development, they were offered few if any roles in the farm management. The study found that the smallholders received dividends of just Rp350, 000 a month (\$US30), well below the minimum wage ( $\mathrm{Li}$ 2011). But even where smallholders managed and controlled their own operations, their productivity fell behind that of the large plantations.

\section{2) The case of Kemitraan in Siak, Riau Province}

To contrast Kemitraan in Sanggau, which is broadly in line with most areas in Indonesia, research was also undertaken in the district of Siak in Riau. Here, the Siak district government had developed a scheme funded under the district budget and administered by the district itself. The district government decided not to develop the nucleus area for a particular estate company, due to the lack of available land. Rather, it developed 8,600 ha of smallholder plots for oil palm development for allocation to poor families. Each family would receive 2- 3 ha of certified mature oil palm. Under the original plan, a district government enterprise (BUMD) would combine with Bogor Agricultural University (IPB) and the State owned enterprise (PTPN5) to form a consortium for developing the palm oil processing factory and the downstream industry, after the trees become mature in 2009.

The district created a cross-agency team to implement the scheme, carrying out a systematic survey of land availability, and selecting the poorest villagers to participate in the schemes. The land owners interested in participating in the schemes and who have more than 9 ha were obliged to release the extra land for the poor landless farmers. The Bupati set up a well-developed internal supervision system to prevent irregularities, attracting the most professional and committed civil servants through extra allowances and additional incentives for officials involved in administering the projects. The State-owned enterprise (PTPN5) functioned as a developer, and the Indonesian Oil Palm Research Institute (IOPRI) operated as the technical monitoring and supervisory agency. Local government utilized revenue generated from oil produced under a joint operation agreement with PERTAMINA, the state oil company, and the local government.

Despite the systematic land inventory system, in a small number of cases village and sub-district actors sold land to outsiders, granted land to those without legitimate entitlements, or allocated land in an underhand fashion. Yet, the methodical process for the collection of data, for assessing land, and settling land entitlements ensured that by and large the policy was implemented as designed, and large scale conflicts were largely avoided.

While the trees have yet to produce fresh fruit bunch (FFB) for smallholders, it is likely that the schemes will reduce poverty for at least 4,000 families. This is because of high subsidies credit (zero interest rate), the high quality planting material, and the fact that farmers also retain alternative income from jungle rubber. However, the final outcome of the scheme will also be affected by the functioning of farmers' cooperatives, the international price of palm oil, and the production levels achieved.

In comparing these examples, it is critical to understand how the design and implementation of the scheme together with how it fits with the agricultural systems and practices of workers and smallholders - cumulatively affect the welfare outcome for smallholders.

While also benefiting the investor, more successful initiatives confer benefits upon participants. In contrast, initiatives that sour relations with villagers, such as the second initiative, have led to the violent death of some company staff in conflicts with villagers. The lack of governance oversight in the Sanggau example sows the seeds for extensive conflict, while the shift in land ownership creates new social and economic issues that will need to be addressed in the future.

\section{INTEGRATION OF LIVESTOCK AND OTHER INITIATIVES}

One venture examined here was by a medium-sized estate company in Sumatra, which, with advice from the Indonesian Oil Palm Research Institute (IOPRI) and the official livestock extension service, in 1996 commenced a scheme for distributing cattle to its 500 employees. The company negotiated and then administered a 7-year loan from the Bank Rakyat Indonesia, which enabled the distribution of three animals to each employee's family. The cattle were grazed under the oil palm, with supplementary feeding on oil palm waste and kernel cake. These animals were used for breeding and fattening, as well as for transporting harvested FFB. By 2003 the number of cattle in the scheme had doubled, while the area harvested per worker had risen from 10 to 15 ha and the incomes of those concerned had been commensurately increased. Interviews with participants in 2003 (Zen et. al. 2006) revealed that the scheme was well managed by the estate staff, who also sought outside professional advice on health and feeding regimes. It also featured excellent continuing relations with the communities involved, and to date, may be judged as an outstanding success (Zen et al 2015). Currently IOPRI's experimental project involving the integration of cattle utilizes oil palm leaves and factory wastes (solid decanter + oil cake sedimentation) for feeding. Animal waste has also been used for making biogas and slurry for making compost. At this scale the experimental project proved a success and it provides a model for improving smallholder income. 


\section{CONCLUSION AND RECOMENDATION}

Large plantation companies, Dinas Perkebunan and IOPRI need to create an integrated dispersal strategy to boost the oil palm productivity of independent smallholders . Farmers participating in dispersal programs require guidance on best plantation practices, high yielding seeds, subsidized fertilizer, pest and plant disease control, and better cooperative management. Local estate companies, Dinas Perkebunan, and IOPRI can scale up the coverage areas and access the budgets to support these programs, from the incorporation of CSR funds and state Budgets (APBD and APBN). The system can set out responsibilities and accountability relationships to support an integrated program. Currently the scale of assistance to independent smallholders is very small. Moreover, assistance is conducted individually by companies or local government. An effective dispersal strategy requires providing extension services to groups of smallholders and cooperatives, stressing compliance with laws and awareness of the importance of protecting remaining forests and biodiversity.

Under Indonesia's decentralization system, local government policies vary from one district to another. Consequently understanding of the importance of smallholder development issues also vary. Therefore, the central government has a critical role to play in raising awareness and improving people's welfare under this dispersal strategy. The national government needs to support local governments to improve the capacity of local government officers (Dinas Perkebunan).

Indonesian government intervention in the palm oil industry has been minimal since 2009, with a consequence that poverty alleviation programs in rural areas has made little if any impact on people living below the poverty line. The rapid expansion of private plantations has provided no opportunity for local people to become independent rich smallholders; instead, they become laborers on their land.

Although this review indicates that the Indonesian government's nucleus estate programs and local government initiatives have had moderate success, we also highlights the difficulties which have plagued program design and implementation, providing several reasons for this. Under the earlier NES and PIR-trans schemes, smallholders had greater direct control over their own plots, and access to modern agronomic and harvesting practice. Under these schemes, the impacts of this autonomy and the assistance offered were quite significant, and smallholders were able to do well. After 1995, given the poorer levels of governance and other problems, policy implementation was more uneven in practice. However such schemes has a more positive impact on the local poor, stimulating the emergence of progressive and independent smallholder.

Following the shift to joint venture and partnership models, oil palm companies gained greater direct control over production. In many cases, landowners then only received an equity share or an annual rental payment from the $20 \%$ of land that is required to be provided to smallholders. In many cases, these benefit-sharing arrangements lacked transparency and were heavily weighted in favor of the plantation. Small-scale farmers were often reduced to becoming laborers on the plantation. The shift to large-scale plantation models meant greater productivity, but it also meant that most of the benefits accrued to plantation companies and to government in the form of taxes. Smallholders did comparatively poorly. In other words, as Cramb's study in Sarawak revealed (Cramb 2013), as production shifted to large-scale models, productivity increased but smallholder returns declined, compared to the model that gave smallholders direct responsibility and control over production.

The more successful programs discussed here are 'targeted microeconomic interventions', which have sought to systematically address incomplete markets for credit and information. The nucleus estates interestingly involved harnessing commercial expertise toward socio-economic goals. In many cases, private estates managed more effectively than their public counterparts, adjusting to the new task and simultaneously increasing commercial returns. The assistance to individual smallholders worked well on a restricted scale, and dovetailed effectively with the efforts of progressive farmers to transform many agrarian contexts. The scarce technical skills and other resources committed to the programs secured estimated average returns to investment little different from those on commercial estates, and occurred within an expanding and competitive industry which consequently distributed its wealth to many more people. These microeconomic interventions, with all their problems, contrast strikingly with the official Indonesian oil palm 'macrointerventions', notably with export taxes, which were broadly unsuccessful (Marks et. al . 1998).

Policy makers can support smallholders by providing for the inter-cropping of oil palm during the immaturity period of 4 years after planting, with additional guidance to settlers in cash cropping and marketing, and with cattle and other highvalue items being included after intercropping has been conducted. These changes can raise participant incomes during the critical early years. The provision of training courses to nucleus estate staff could increase the transfer of technologies, and improve staff capacity to deal more effectively with land transfers and sustain good community relations.

State policy makers could also support the guidance and supervision of cooperatives, particularly when oil palm reaches its mature period. Interest and loan repayments could be made more flexible, with lower deductions during years of smaller yields.Measures are required by central and local governments, to overcome the procedural unfairness of the land acquisition process and credit and benefit sharing arrangements. Policies and schemes can help secure the rights, resources and livelihoods of the rural poor, but policies can also contribute to the misappropriation and misuse of land and other resources. Therefore, simple clear regulatory guidelines need to be developed alongside lucid, publicly available and enforceable service standards for public agencies involved in plantation processes. 
The approach to individual smallholdings also requires adequate finance, which might be provided by the state through a special fund, enabling less well-endowed provinces to parallel the efforts in Riau and North Sumatra. The emphasis of this much less expensive program can be placed on nurseries providing reputable high-yielding planting materials, whose price might be subsidized to stimulate adoption. The model of IOPRI could be scaled up to reach poor people in rural areas. Local extension centers can support this initiative by providing technical advices. It is of concern that over half of individual smallholder plantings are still being planted using inferior low-yielding seedlings, and it is crucial that this practice is curbed, given that it almost halves the output of CPO over the succeeding 25 years.

\section{ACKNOWLEDGMENT}

This work was supported by High Carbon Stock (HCS) Science Study 2015 (Consulting Study 14: High Carbon Stock and the Socio-Economics of Palm Oil -Towards Improving the Sustainability of the Palm Oil Sector in Indonesia).

\section{REFERENCES}

[1] Barlow,C. and Muharminto (1982), Smallholder Rubber in South Sumatra. Towards Economic Improvement, Bogor: Balai Penelitian Perkebunan.

[2] Barlow, C (2001), 'The Role of Institutions in Planting Improved Smallholder Rubber', in Robert Yapo Assamoi, Kees Burger, Dominique Nicolas, Francois Ruf and Patrice de Vernou (2002) (eds), The Future of Perennial Crops. Investment and Sustainability in the Humid Tropics, Montpellier: Centre de Cooperation Internationale en Recherche Agronomique pour le Developpement and BNETD.

[3] Direktorat Jenderal Bina Produksi Perkebunan (2008), Statistik Perkebunan Indonesia, 2001-2007 [Statistics of Indonesia Tree Crop Farms, 2001-2007], Jakarta: Departemen Pertanian.

[4] Direktorat Jenderal Perkebunan (2008), Kebijakan pengembangan kelapa sawit Indonesia, Paper on internal seminar of Bank NISP, 15 Februari 2008 at Bank NISP Tower, Jakarta Selatan.
[5] Dove, M. (1986). The practical reason of weeds in Indonesia: Peasant vs. state views of Imperata and Chromolaena, Human Ecology 14(2) pp 163-190

[6] Graham, E. and Floering, I. (1984), the Modern Plantation in the Third World, London and Sydney: Croom Helm.

[7] Marks, Stephen V. Donald F. Larson and Jacqueline Pomeroy (1998), 'Economic Effects of Taxes on Oil Palm Products', Bulletin of Indonesian Economic Studies, Vol. 34, No. 3, pp. 37-58

[8] McCarthy, JF., P. Gillespie and Z. Zen (2012) "Swimming Upstream: Local Indonesian Production Networks in "Globalized" Palm Oil Production." World Development 40(3), March 2012

[9] McCarthy, JF. (2010) Processes of inclusion and adverse incorporation: oil palm and agrarian change in Sumatra, Indonesia Journal of Peasant Studies, 37(4) pp $821-850 \ldots \ldots$.

[10] McCarthy, JF. and Z Zen. (2010) Regulating the Oil Palm Boom: Assessing the Effectiveness of Environmental Governance Approaches to Agro-industrial Pollution in Indonesia Law \& Policy 32(1) pp 153 179

[11] Soeleiman (2000), Tanah Adat. Kenyataan Empiris Implementasi Hukum Tanah Nasional di Sumatera Selatan [Traditional Land. Empirical Reality in Implementing the National Land Rights of South Sumatra], Palembang

[12] Soeleiman (2000), Tanah Adat. Kenyataan Empiris Implementasi Hukum Tanah Nasional di Sumatera Selatan [Traditional Land. Empirical Reality in Implementing the National Land Rights of South Sumatra], Palembang

[13] Zen, Z. (1998), Towards a More Sustainable Natural Rubber Industry in Indonesia, the Special Role of Smallholders, unpublished Ph.D. Thesis, Perth: Murdoch University

[14] Zen, Z., Zulkifli Lubis, and Suzanna Edyono (2003), Social Mapping and Identification of Strategic Issues in Communities Surrounding PT X at Kabupaten Y in Sumatra, Medan: Universitas Muhammadiyah.

[15] Zen, Z., Barlow, C. and Gondowarsito, R. (2006), 'Oil palm in Indonesian socio-economic improvement: a review of options', Industry Economic Journal, Vol. 6, pp18 - 29

[16] Zen, Z., McCarthy, J. and Gillespie (2008), Linking pro-poor policy and oil palm cultivation, Policy Brief 5 (2008) Australia Indonesia Governance Research Partnership, Crawford School of Economics and Government, ANU Collage of Asia and the Pacific, The Australian National University 